Volume 1 Issue 1 (2017) Pages 52 - 61

Jurnal Obsesi : Jurnal Pendidikan Anak Usia Dini

DOI: $10.31004 /$ obsesi.v1i1.30

\title{
Penggunaan Model Pembelajaran Pendidikan Karakter Abad 21 pada Anak Usia Dini
}

\author{
Yenni Fitra Surya ${ }^{\bowtie}$ \\ Prodi PGSD Fakultas Ilmu Pendidikan \\ Universitas Pahlawan Tuanku Tambusai Riau
}

\begin{abstract}
Abstrak
Pendidikan karakter mutlak dilaksanakan pada abad 21 pada anak usia dini sebagai langkah kuratif dan patologi sosial di masyarakat, namun langkah preventif guna pembentukan karakter baik dari setiap pesera didik belum efektif digunakan dalam pendidikan karakter. Di dalam pembelajaran selain kognitif pembetukan karakter siswa harus perlu diperhatikan. Pada kenyataannya acapkali pembetukan karakter sejak dini ini sering terlupakan. Tujuan penelitian menjelaskan secara komprehensif hakikat pendidikan karakter pada abad 21 pada anak usia dini, menjelaskan secara komprehensif penggunaan model-model pembelajaran dalam pendidikan karakter pada abad 21 pada anak usia dini, menjelaskan secara komprehensif penggunaan pendekatan pembelajaran dalam pendidikan karakter pada abad 21 pada anak usia dini. Adapun metode penelitian yang digunakan dalam penelitian ini adalah kajian pustaka yaitu menghubungkan penelitian dengan literatur yang ada dan mengisi celah dalam penelitian sebelumnya. Hasil penelitian yang diperoleh pada penelitian ini penggunaan model pembelajaran pendidikan karakter pada abad 21 pada anak usia dini merupakan proses pemberdayaan potensi peserta didik proses humanisasi (humanizing), dan proses pembudayaan, model-model pembelajaran pendidikan yaitu model pembelajaran penanaman nilai, berbasis perkembangan penalaran moral, analisis nilai dan project citizen, efektif digunakan membantu peserta didik mengembangkan kompetensi menjadi warga negara yang baik.
\end{abstract}

Kata Kunci :Model Pembelajaran, Pendidikan Karakter Abad 21, Anak Usia Dini

\begin{abstract}
Absolute character education was undertaken in the 21 st century in early childhood as curative measures and social pathology in the community, but a preventive measure to the formation the good character of each student have not effectively used in character education. In addition to cognitive learning students' character formation should be noted. In fact, often the formation of character early on is often forgotten. The aim of research explained comprehensively the nature of character education in the 21st century in childhood, explained comprehensively the use of models of learning in character education in the 21st century in childhood, explained comprehensively use learning approaches in character education in the 21 st century to children aged early. The research method used in this study is a literature review is to connect research with the existing literature and fills the gaps in previous research. The results obtained in this study the use of the learning model of character education in the 21 st century in childhood is the process of empowering the learner process of humanization (humanizing), and the process of acculturation, learning models of education namely learning model planting value, based on the development of moral reasoning, value analysis, and project citizen, effective use helps learners develop competencies become good citizens.
\end{abstract}

Keywords: Learning Model, 21st Century Character Education, Childhood

@ Jurnal Obaesi Prodi PG-PAUD FIP UPTT 2017

$\triangle$ Corresponding author :

Address : Jalan Sungai Kampar 32 Bangkinang Kab. Kampar ISSN 2356-1327 (Media Cetak)

Email : yenni.fitra13@gmail.com

ISSN 2549-8959 (Media Online) 


\section{PENDAHULUAN}

Era globalisasi yang ditandai oleh perkembangan ilmu pengetahuan dan teknologi yang amat pesat, terutama teknologi informasi dan komunikasi, telah mengubah dunia seakan-akan menjadi kampung dunia (global village). Dunia menjadi transparan tanpa mengenal batas negara. Kondisi yang demikian itu berdampak pada seluruh aspek kehidupan bermasyarakat, berbangsa dan bernegara. Di samping itu, dapat pula mempengaruhi pola pikir, pola sikap, dan pola tindakan seluruh masyarakat Indonesia. Fenomena globalisasi telah menantang kekuatan penerapan unsur-unsur karakter bangsa (Budimansyah, 2010). Pendidikan bagi anak usia dini memberikan upaya untuk menstimulasi, membimbing, mengasuh dan pemberian kegiatan pembelajaran yang akan menghasilkan kemampuan dan ketrampilan anak. Pendidikan anak usia dini adalah bentuk penyelenggaraan pendidikan yang menitik beratkan pada peletakan dasar ke arah pertumbuhan dan perkembangan fisik, kecerdasan, daya cipta, kecerdasan emosi, dan kecerdasan spititual. Pendidikan anak usia dini yang dilakukan orang tua berikan bagi anak merupakan suatu persiapan kematangan anak dalam menghadapi perkembangannya di masa yang akan datang (Pascalian Hadi Pradana, 2016).

Membangun keberadaan bangsa yang berkarakter pada abad 21 merupakan conditio zine quo non bagi Bangsa Indonesia. Hal ini diwujudkan jika setiap warga negara Indonesia sebagai pendukung utama peradaban memiliki karakter bangsa yang luhur dalam rangka membangun keberadaban bangsa(Sukadi, 2007). Walaupun sudah diselenggarakan melalui berbagai upaya, pembangunan karakter bangsa belum terlaksana secara optimal dan pengaruhnya terhadap pembentukan karakter baik (good character) warganegara belum cukup signifikan (Budimansyah, 2010: 2).

Dalam tujuan Pendidikan Nasional sesungguhnya sudah memiliki kandungan nilai-nilai karakter yang sangat kaya. Undang-undang Nomor 20 Tahun 2003 tentang Sistem Pendidikan Nasional Pasal 1 ayat 14 menyatakan bahwa PAUD adalah suatu upaya pembinaan yang ditujukan kepada anak sejak lahir sampai dengan usia enam tahun yang dilakukan melalui pemberian rangsangan pendidikan untuk membantu pertumbuhan dan perkembangan jasmani dan rohani agar anak memiliki kesiapan dalam memasuki pendidikan lebih lanjut. Hal ini menjadi tantangan tersendiri bagi institusi pendidikan dan para pendidik bagaimana menerjemahkan tujuan Pendidikan Nasional tersebut menjadi strategi, model, dan pendekatan pembelajaran hingga secara efektif mampu menumbuhkan nilainilai karakter yang dicita-citakan. Namun pada hakikatnya tidak ada proses pendidikan yang bebas nilai, tidak ada juga sebuah nilai yang bebas rujukan.Setiap pendidikan berkesempatan mengembangkan model dan pendekatan pembelajaran dalam pendidikan karakter yang diinginkan dapat dikembangkan secara terpadu melalui manajamen pendidikan dan pembelajaran berlandaskan pada nilai-nilai yang menjadi rujukan (Ace, 2010: 122).

Ada beberapa penggunaan model dan pendekatan pembelajaran pendidikan karakter pada abad 21yaitu; pendekatan keteladanan, pendekatan berbasis kelas, pendekatan kegiatan ko-kurikuler dan ekstrakurikuler, pendekatan kultur kelembagaan dan kultur akademik, pendekatan berbasis komunitas, dan dukungan kebijakan pendidikan yang relevan serta model pembelajaran penanaman nilai, berbasis perkembangan penalaran moral, analisis nilai, dan project citizen yang dapat dikembangkan guna pembentukan karakter baik (good character) setiap peserta didik. Tujuan penelitian menjelaskan secara komprehensif hakikat pendidikan karakter pada abad 21 pada anak usia dini, menjelaskan secara komprehensif penggunaan model-model pembelajaran dalam pendidikan karakter pada abad 21 pada anak usia dini, menjelaskan secara komprehensif penggunaan pendekatan 
pembelajaran dalam pendidikan karakter pada abad 21 pada anak usia dini.

Metode penelitian yang digunakan dalam penelitian ini adalah kajian pustaka. Semua jenis penelitian memerlukan studi pustaka khususnya jenis penelitian historis yang semua data-data sebagian besar diperoleh melalui kajian pustaka. Namun kajian pustaka tentu saja tidak hanya sekedar urusan membaca dan mencatat literatur atau buku-buku sebagaimana yang sering dipahami banyak orang. Apa yang disebut dengan riset perpustakaan atau sering juga disebut studi pustaka, ialah serangkaian kegiatan yang berkenaan dengan metode pengumpulan data pustaka, membaca dan mencatat serta mengolah bahan penelitian (Mestika Zed,2004:3).

\section{PEMBAHASAN}

Dalam undang-undang tentang sistem pendidikan nasional dinyatakan bahwa pendidikan anak usia dini adalah suatu upaya pembinaan yang ditujukan kepada anak sejak lahir sampai dengan usia enam tahun yang dilakukan melalui pemberian rangsangan pendidikan untuk membantu pertumbuhan dan perkembangan jasmani dan rohani agar anak memiliki kesiapan dalam memasuki pendidikan lebih lanjut (UU Nomor 20 Tahun 2003 Bab I Pasal 1 Ayat 14). Kegiatan pembelajaran pada anak usia dini, menurut Sujiono dan Sujiono (Yuliani Nurani Sujiono, 2009: 138), pada dasarnya adalah pengembangan kurikulum secara konkret berupa seperangkat rencana yang berisi sejumlah pengalaman belajar melalui bermain yang diberikan pada anak usia dini berdasarkan potensi dan tugas perkembangan yang harus dikuasainya dalam rangka pencapaian kompetensi yang harus dimiliki oleh anak, Salah satunya dengan pendekatan karakter (moral education)

Penguatan pendidikan moral (moral education) atau pendidikan karakter (character education) dalam konteks sekarang sangat relevan untuk mengatasi krisis moral yang sedang melanda di negara kita. Krisis tersebut antara lain berupa meningkatnya pergaulan bebas, maraknya angka kekerasan anak-anak dan remaja, kejahatan terhadap teman, pencurian remaja, kebiasaan menyontek, penyalahgunaan obat-obatan, pornografi, dan perusakan milik orang lain sudah menjadi masalah sosial yang hingga saat ini belum dapat diatasi secara tuntas, oleh karena itu betapa pentingnya pendidikan karakter.

Pendidikan karakter pada abad 21 sesungguhnya tidak bisa dilepaskan dari program pendidikan pada umumnya. Karena itu, untuk memahami makna pendidikan karakter tidaklah bisa dilepaskan dari makna pendidikan itu sendiri. Landasan pendidikan nasional Indonesia sesungguhnya adalahpembentukan karakter kehidupan berbangsa. Demikian pula dengan berakar pada nilai-nilai agama, kebudayaan nasional Indonesia, dan tanggap terhadaptuntutan perubahan jaman jelas menunjukkan bahwa jiwa atau roh pendidikannasional itu sesungguhnya pembentukan karakter atau kepribadian bangsa Indonesia yang bersumber dan nilai-nilai agama, nilai-nilai luhur kebudayaannasional, dan nilai-nilai yang tumbuh dan berkembang dalam pertumbuhan dan perkembangan jaman (Sukadi, 2011: 96).

Menurut (Koesoema, 2010) roh pendidikan karakter dapat menjadi pisau bermata dua. Di satu sisi pendidikan karakterdapat memacu dan meningkatkan kemampuan intelektual dan akademis, di sisi lain pendidikan karakter menjadi usaha pemertahanan dan pengembangan kapasitas moral peseta didik. Kedua kekuatan ini menjadi idealisme pendidikan agar dapat mengarahkan peseta didik semakin mampu mengembangkan ketajaman intelaktual dan integritas diri sebagai pribadi yang memiliki karakter kuat. Demikian pula pendidikan tanpa jiwa dan spirit yang jelas dalam bentuk pendidikan karakter diyakini akan dapat menjadi bumerang bagi kepentingan kemanusiaan itu sendiri. Diperlukan penanaman nilai-nilai dan norma-norma Agama yang kuat terhadap bangsa ini agar tidak mudah 
terpengaruh dan mempunyai filter ketika pengaruh-pengaruh bangsa lain masuk. Supaya penanaman nilai dan norma tersebut kuat, maka harus dilakukan sejak usia dini, sebagaimana disampaikan oleh Hasan A. (dalam Barr A.tt:357) bahwa mencari ilmu pada saat kecil seperti memahat di atas batu dan mencari ilmu diwaktu tua bagaikan mengukir diatas air. Ungkapan ini menekankan pentingnya belajar pada usia dini, sebab belajar yang dilakukan walaupun melalui proses yang tidak mudah namun apabila sudah dikuasai, maka akan tetap diingat sepanjang hidupnya. (Fauziddin, 2016) Moral dan moralitas memiliki sedikit perbedaan, karena moral adalah prinsip baik-buruk sedangkan moralitas merupakan kualitas pertimbangan baikburuk. Dengan demikian, hakekat dan makna moralitas bisa dilihat dari cara individu yang memiliki moral dalam mematuhi maupun menjalankan aturan.

Hal ini sangat jelas dinyatakan oleh Mahatma Gandhi bahwa pendidikan tanpa basis karakter adalah salah satu dosa yang fatal Theodore Roosevelt juga pernah menyatakan bahwa: "to educate a person in mind and not in morals is to educate a menace to society (Williams dan Megawangi, 2010). Hal senada juga pernah dinyatakan oleh Horace Man bahwa "the highestand noblest office of education pertains to our moral nature. The common school should teach virtue before knowledge, for knowledge without virtue poses its own dangers (Elmubarok, n.d.), 2008: 106).

Salah satu tujuan nasioanal bangsa yang paling utama ialah mencerdaskan kehidupan bangsa, dalam hal ini dibutuhkan suatu sarana serta prasarana yang dijadikan suatu penyaluran serta dijadikan sebagai ajang terwujudnya tujuan nasioanl bangsa tersebut. Dalam hal ini pendidikanlah satu-satunya yang menjadi sarana prasarana nomor satu dalam pencapaian tujuan pendidikan tersebut. Negara sendiri ingin mewujudkan suatu sistem dengan iklim pendidikan nasional yang demokratis dan bermutu guna memperteguh akhlak mulia, kreatif, inovatif, berwawasan kebangsaan, cerdas, sehat, berdisiplin dan bertanggungjawab, berketerampilan serta menguasai ilmu pengetahuan dan teknologi dalam rangka mengembangkan kualitas manusia Indonesia.

Akan tetapi dengan era modern serta menjalarnya arus globalisasi membuat sebagian tujuan dari nasional bangsa tersebut menjadi terhambat bahkan dapat dikatakan rusak. Hal tersebut dapat dilihat dengan semakain rusaknya moral serta anak bangsa pada saat ini, terutama moral serta akhlak anak bangsa yang masih duduk dibangku sekolah. Semakin terjadinya krisis moral serta akhlak yang dihadapai oleh dunia pendidikan tersebut, saat ini pemerintah mencanangkan kembali sistem pendidikan yang berdasarkan akhlak serta penanaman moral yang kuat terhadap peserta didik. Untuk mencegah lebih parahnya krisis akhlak, kini upaya tersebut mulai dirintis melalui pendidikan karakter bangsa. Dalam hal ini jelas saja pendidikan moral menjadi pendidikan paling utama setelah diadakannya pendidikan karakter untuk mengatasi krisis moral yang sedang terjadi melanda negara kita.

Krisis moral tersebut jelas sekali digambarkan dengan semakinmaraknya pergaulan bebas yang menimpa anak sekolah, maraknya angka kekerasan yang terjadi dikalangan remaja, penyalahgunaan obat-obatan, pornografi, dan perusakan milik orang lain sudah menjadi masalah sosial yang hingga saat ini belum dapat diatasi secara tuntas, oleh karena itu betapa pentingnya pendidikan karakter. Dalam hal ini Lickona menyebutkan dengan artian yang sederhana mengenai pendidikan karakter, yaitu sebuah pendidikan yang dilakukan untuk memenuhi isi jiwa peserta didik dengan karakter yang bermoral serta berakhlak baik. Suyanto sendiri yang seorang ahli pendidikan mendefinisikan karakter sebagai cara berpikir dan berperilaku yang menjadi ciri khas tiap individu untuk hidup dan bekerja sama, baik dalam lingkup keluarga, masyarakat, bangsa, maupun negara. Sehingga dari kedua pengertian diatas pendidikan 
karakter dianggap sangat penting dan sudah sepatutnya mendapat perhatian khusus dari negara ini dalam rangka mewujudkan cita-cita anak bangsa serta menghasilkan generasi muda yang berkualitas.

Pendidikan karakter dapat diartikan sebagai the deliberate us of all dimensions of school life to foster optimal character development yang dapat diartikan sebagai suatu usaha kita secara sengaja dari seluruh dimensi kehidupan sekolah/madrasah untuk membantu pembentukan karakter secara optimal. Dalam melaksanakan pendidikan yang berkarakter tentu saja dibutuhkan suatu cara atau metode tertentu untuk mewujudkan tujuan dari pendidikan itu sendiri. Metode yang dapat dilakukan dapat berupa metode keteladanan.

Sesungguhnya pendidikan karakter adalah proses pemberdaan (empowering) potensi peserta didik proses humanisasi (humanizing), dan proses pembudayaan (civilizing). Sebagai proses pemberdayaan, pendidikan karakter pada dasarnya adalah usaha sadar untuk memberdayakan dan mengembangkan seluruh potensi peserta didik. Proses ini juga memberdayakan peserta didik sebagai makhluk yang menyadari memiliki sejumlah potensi dan menyadari keterbatasannya dengan cara knowing the what and knowingthe why; appreciate mean and end; dan experincing, acting, and behaving. Pendidikan karakter juga bukanlah proses pengajaran yang bersifat transfer informasi semata. Pendidikan karakter juga bukanlah proses penanaman nilai-nilai belaka.

Di sisi lain, potensi-potensi itu bisa dimanifestasikan dalam bentuk multi kecerdasan: pengetahuan fisik, kinestetik, emosional sosial, intelektual, moral, estetis, dan spiritual. Yang lain lagi berusaha mewujudkan potensi-potensi itu dan segi: learning to know, learning to do, learning to be, learning to live together, dan learning to obey God Almighty. Kesadaran yang lain dapat mengintegrasikan potensi-potensi: kemampuan berpikir yang baik dan benar, berkata-kata yang baik dan benar, dan berbuat yang baik dan bijaksana. Yang lainnya lagi dapat pula diintegrasikan antara kemampuan, kepribadian, dan skills atau keterampilan (Sukadi, 2007).

Lahirnya pendidikan karakter bisa dikatakan sebagai sebuah usaha untuk menghidupkan spiritual yang

ideal. Foerster seorang ilmuan pernah mengatakan bahwa tujuan utama dari pendidikan adalah untuk membentuk karakter karena karakter meru pakan suatu evaluasi seorang pribadi atau individu serta karakter pun dapat memberi kesatuan atas kekuatan dalam mengambil sikap di setiap situasi. Pendidikan karakter pun dapat dijadikan sebagai strategi untuk mengatasi pengalaman yang selalu berubah sehingga mampu membentuk identitas yang kokoh dari setiap individu dalam hal ini dapat dilihat bahwa tujuan pendidikan karakter ialah untuk membentuk sikap yang dapat membawa kita kearah kemajuan tanpa harus bertentangan dengan norma yang berlaku. Pendidikan karakter pun dijadikan sebagai wahana sosialisasi karakter yang patut dimiliki setiap individu agar menjadikan mereka sebagai individu yang bermanfaat seluasluasnya bagi lingkungan sekitar. Pendidikan karakter bagi individu bertujuan agar :

1. Mengetahui berbagai karakter baik manusia.

2. Dapat mengartikan dan menjelaskan berbagai karakter.

3. Menunjukkan contoh prilaku berkarakter dalam kehidupan sehari-hari.

4. Memahami sisi baik menjalankan prilaku berkarakter.

\section{A. Model Pembelajaran Pendidikan Karakter}

Model pembelajaran merupakan cara atau teknik penyajian yang digunakan guru dalam proses pembelajaran agar tercapai tujuan pembelajaran. Ada beberapa model-model pembelajaran seperti ceramah, diskusi, demonstrasi, studi kasus, bermain peran (role play) dan lain sebagainya. Yang tentu saja masingmasing memiliki kelemahan dan kelebihan. Menurut Slavin Pembelajaran didefinisikan 
sebagai perubahan tingkah laku individu yang disebabkan oleh pengalaman sedangkan Woolfolk mengatakan pembelajaran berlaku apabila sesuatu pengalaman secara relatifnya menghasilkan perubahan kekal dalam pengetahuan dan tingkah laku dan Crow \& Crow mengatakan bahwa pembelajaran adalah pemerolehan tabiat, pengetahuan dan sikap

Berdasarkan defenisi di atas dapat disimpulkan bahwa pembelajaran adalah perubahan tingkah laku yang melibatkan ketrampilan kognitif yaitu penguasaan ilmu dan perkembangan kemahiran intelektual. Proses pembelajaran lebih bermakna jika guru dalam membelajarkan siswa dengan menggunakan model pembelajaran yang bervariasi. Model pembelajaran diartikan sebagai prosedur sistematis dalam mengorganisasikan pengalaman belajar untuk mencapai tujuan belajar. Dapat juga diartikan suatu pendekatan yang digunakan dalam kegiatan pembelajaran. Salah satu yang dapat digunakan yaitu model pendekatan karakter.

Persoalan pendidikan karakter
di Indonesia sejauh menyangkut pendidikan moral dan dalam aplikasinya terlalu membentuk satu arah pembelajaran khusus sehingga melupakan mata pelajaran lainnya, dalam pembelajaran terlalu membentuk satu sudut kurikulum yang diringkas kedalam formula menu siap saji tanpa melihat hasil dari proses yang dijalani. Guru/dosen pun cenderung mengarahkan prinsip moral umun secara satu arah, tanpa melibatkan partisipasi siswa untuk bertanya dan mengajukan pengalaman empiriknya. Sejauh ini dalam proses pendidikan di Indonesia yang

berorientasi pada pembentukan karakter individu belum dapat dikatakan tercapai karena dalam prosesnya pendidikan di Indonesia terlalu mengedepankan penilian pencapaian individu dengan tolak ukur tertentu terutama logik-matematik sebagai ukuran utama yang menempatkan seseorang sebagai warga kelas satu. Dalam prosesnya pendidikan karakter yang berorientasi pada moral dikesampingkan dan akibatnya banyak kegagalan nyata pada dimensi pembentukan karakter individu

contohnya Indonesia terkenal di pentas dunia karena kisah yang buruk seperti korupsi dengan moralitas yang lembek.

Pendidikan karakter bukan hal baru dalam tradisi pendidikan di Indonesia.

Beberapa pendidik Indonesia modern yang kita kenal seperti Soekarno telah mencoba menerapkan semangat pendidikan karakter sebagai pembentuk kepribadian dan identitas bangsa yang bertujuan menjadikan bangsa Indonesia menjadi ban gsa yang berkarakter. Pendidikan karakter merupakan aspek yang penting bagi generasi penerus. Seorang individu tidak cukup hanya diberi bekal pembelajaran dalam hal intelektual belaka tetapi juga harus diberi hal dalam segi moral dan spiritualnya, seharusnya pendidikan karakter harus diberi seiring dengan perkembangan intelektualnya yang dalam hal ini harus dimulai sejak dini khususnya dilembaga pendidikan. Pendidikan karakter di sekolah dapat dimulai dengan memberikan contoh yang dapat dijadikan teladan bagi murid dengan diiringi pemberian pembelajaran seperti keagamaan dan kewarganegaraan sehingga dapat membentuk individu yang berjiwa sosial, berpikir kritis, memiliki dan mengembangkan cita-cita luhur, mencintai dan menghormati orang lain, serta adil dalam segala hal. Menurut (Sukadi, 2007) ada beberapa model pembelajaran pendidikan karakter pada abad 21 yang berbasis pada pendidikan nilai dan moral perlu disajikan, antara lain:

1. Model pembelajaran penanaman nilai, berasumsi bahwa peserta didik perlu menerima nilai- nilai yang dianggap luhur oleh masyarakat, baik yangberupa nilai-nilai lama yang masih dianggap luhur maupun nilai-nilai modernyang telah diterima oleh dominan dalam masyarakat. Model pembelajaran nilai seperti ini berasal dan keyakinan ideologi pendidikan perenialisme danesensialisme. Ciri 
utama pembelajaran penanaman nilainilaiadalah bahwa para siswa/ mahasiswa harus menerima nilai-nilai yang diajarkanoleh orang dewasa dan mereka harus mengubahnilai-nilai yang dianggap tidakrelevan oleh kelas dominan dalam masyarakat. Pembelajaran penanaman nilai-nilai ini dapat dilakukan melalui metode pengajaran langsung atau dengan ceramah nilai-nilai, pembelajarandengan simulasi, bermain peran, bermain drama, belajar dengan melakukan,dan belajar dengan penguatan positif dan negatif.

2. Model pembelajaran berbasis perkembangan penalaran moral, menurutPiaget, perkembangan penalaran moral itu berkembang dan tingkat heteronommenuju pengambilan keputusan moral yang bersifat otonom. Untuk memfasilitasi peserta didik mampu mengambil keputusanmoral secara otonom, mereka haruslth diajarkan untuk berhadapan dengandilema nilai moral, belajar membuat keputusan moral, dan belajar memberikan pertimbangan nilai-nilai moral dengan menggunakan penalaran yang rasional.Melalui diskusi kelompok peserta didik diajak untuk mendiskusikan secara rasional mengapa mereka harus mengambil keputusan moral seperti yang mereka hadapi dengan landasan berpikir secara rasional.

3. Model pembelajaran analisis nilai, menekankan pada kemampuan peserta didik untuk melakukan analisis nilainilaisecara rasional dan logis pada masalah-masalah sosial yang mengandungmuatan nilai-nilai moral. Pembelajaran dengan analisis nilai ini menghadapkanpeserta didik pada berbagai masalah sosial yang ada di masyarakat yangmengandung muatan konflik nilai-nilai moral. Tugas siswa atau mahasiswaadalah melakukan analisis secara logis baik melalui kajian pustaka, melakukanpenelitian lapangan, maupun melalui diskusi secara kelompok atau kelas untuk membahas berbagai konflik nilai yang terjadi pada masalah-masalahsosial tersebut.

4. Model pembelajaran project citizen, membantu peserta didik mengembangkan

kompetensi menjadi warga negara yang baik dalam arti demokratis dan partisipatif. Peserta didik diberdayakan untuk memiliki kepekaan dankepedulian sosial dalam turut mempengaruhi kebijakan publik oleh pemerintah

yang mengandung muatan nilai-nilai moral. Di sini peserta didik belajar mengidentifikasi masalah-masalah sosial atau mengidentifikasi kebutuhanmasyarakat yang dapat dibantu pemenuhannya melalui usulan kebijakan publik yang dikembangkan sendiri oieh peserta didik. Setelah itu pesertadidik belajar membuat berbagai alternatif pemecahan masalah dan menyusunrekomendasi untuk usulan kebijakan publik kepada pejabat pemerintahan terkait. Terakhir, peserta didik bersama-sama pendidik dapat melakukantindakan refleksi pengalaman belajar untuk menilai efektivitas pembelajarandalam mencapai tujuantujuan pendidikan nilai/moral (Sukadi, 2007).

\section{B. Pendekatan Pendidikan Karakter}

(Sukadi, 2007) menyatakan bahwa pendidikan karakter mengambil aspek yang dominan dan utama dalam pelaksanaan program pendidikan. Demikian pula pendidikan karaktermengambil domain yang terdalam dan kompleks dalam pengembangan kompetensi manusiawi. Sangatlah tidak mudah, karena itu, untuk melakukandan mengembangkan satu pendekatan pendidikan karakter yang efektif dan efisien. Tidak seperti pendidikan bidang studi atau mata pelajaran yang bersifatkognitif atau keterampilan tertentu yang umumnya bisa efektif dilaksanakan melalui pendekatan pembelajaran bidang studi tertentu, pendidikan karakter yang cenderung utuh mengintegrasika domaindomain kemampuan kepribadian, dan 
keterampilan agak sulit dijamin efektivitasnya jika dibelajarkan melalui mata pelajaran karakter yang berdiri sendiri.

Ada beberapa pendekatan pendidikan karakter yang mungkin dilaksanakan di sekolah atau perguruan tinggi dengan menggunakan beberapa pendekatan yang telah disebutkan di atas, yaitu; pendekatan keteladanan, pendekatan berbasis kelas, pendekatan kegiatan kokurikuler dan ekstrakurikuler, pendekatan kultur kelembagaan dan kultur akademik, pendekatan berbasis komunitas, dan dukungan kebijakan pendidikan yang relevan.

1. Pendekatan keteladanan, merupakan pendekat untuk meneladankan pola berpikir, nilai-nilai dan sikap, serta kompetensi yang mencerminkan teraktualisasikannya nilai-nilai yang mendasari karakter bangsa dari seseorang kepada orang lain terutama dari orang dewasa kepadapeserta didik, dengan maksud peserta didik tersebut dapat mengikuti pola-pola perilaku yang baik dari model (Sukadi, 2007). Pendekatan ini tidaklah cukup dilakukanhanya dengan memberikan contoh-contoh pola berpikir nilai dan sikap, serta perilaku yang baik kepada peserta didik, karena pemberian contoh yang tidakdisertai dengan pemilikan perilaku tersebut oleh model justru dapat menjadi bumerang. Untuk kepentingan ini seluruh komponen civitas akademika(pemimpin perguruan tinggi, kepala sekolah, staf dosen, guru staf, dan mahasiswa atau siswa) haruslah mampu mengternalisasikan nilai-nilai karakter kehidupan berbangsa dan menjadi teladan yang baik bagipembangunan karakter bangsa satu sama lain.

2. Pendekatan berbasis kelas, dapat dilakukan dalamhubungan dialogis melalui kegiatan pembelajaran di kelas. Di sini ada guru ataudosen sebagai pendidik dan mahasiswa atau siswa sebagai pembelajar. Kegiatanpembelajaran pendidikan karakter dapat dilakukan melalui pemberdayaanpeserta didik dalam membina nilai-nilai utama dalam pembentukan karakteryang diharapkan.

Untuk ini guru dan siswa, misalnya, perlu menyepakatitentang nilai-nilai utama yang akan dibina, dimantapkan, dikuatkan, dandikembangkan sebagai kompetensi yang akan dicapai dalam pembelajaran. Selanjutnya, guru dapat memfasilitasi, membimbing, mendorong, menemani,mangarahkan, memimpin, menguatkan, dan menyontohkan atau meneladankan kepada peserta didik bagaimana nilainilai keutamaan karakter tersebutdigali atau dieksplorasi, dijelaskan, diberi penalaran, dinilai dan disikapi,dihayati, dipecahkan konflik-konfliknya, dan dilaksanakan dalam kehidupanseharihari, serta dimonitoring dan dievaluasi efektivitas penyelenggaraanpendidikannya.

3. Pendekatan integritas dalam kegiatan ekstrakulikuler, (Sukadi, 2007) hampir identik dengan pendekatan berbasis kelas yang bersifat atau berbasis kegiatan kurikuler dan kokurikuler, pendidan karakter jugadapat diintegrasikan ke dalam kegiatan kepemimpinan siswa/mahasiswa dan kegiatan ekstrakurikuler kesiswaan/kemahasiswaan. Untuk ini seluruh organisasi kepemimpian siswa/mahasiswa dan organisasi ekstra kampus atau ekstrakurikuler di bawah bimbingan dan pembinaan dosen harusah dapat dengan sengaja di sistematis mengembangkan proramprogram pendidikan yang dapat mengintegrasikan tujuan-tujuan pendidiksan karakter sesuai dengan visi, misi,tujuan, jeins program, dan kegiatan masing-masing unit organisasi kesiswaan/kemahasiswaan.

Untuk efekfivitas pendekatan ini, seluruh siswa dan guru atau mahasiswa dan dosen pembimbing haruslah memiliki dasar, komitmen, program, dan tindakan yang sama dalam mengembangkan iklim organisasi kesiswaan/kemahasiswaan dalam mengembangkan kegiatan-kegiatan 
ekstra yang dapat memfasilitasi pencapaian tujuan untuk terbangun dan terinternalisasikan nilai-nilai kepribadian bangsa sebagaimana dirumuskan dalam kompetensi pendidikan karakter bangsa.

4. Pendekatan pengembangan kultur sekolah atau kulturakademik,tidak saja mengandalkan pembelajaran di kelas, tetapi juga yang lebih penting adalah bagaimana dapat dibangun pranata sosial dan budaya serta penciptaan iklim akademis yang mencerminkan terwujudkannya nilainilai keutamaan dalam pendikan karakter (Sukadi, 2007). Untuk ini semua komponen civitas akademik tentu haruslah memiliki visi, misi, pola ilmiah pokok, rencana dan kebijakan strategis, pola berpikir, nilai-nilai dan sikap, serta pola tindakan dengan dasar komitmen yang sama untuk mewujudkan roh atau jiwa dan nilainilai keutamaan dalam iklim pendidikan karakter di lembaga.

Dengan begini tugas dan tanggung jawab pencapaian kompetensi pendidikan karakter tidaklah monopoli guru atau dosen semata, tetapi juga menjadi peran dan tanggung jawab pemimpin lembaga, staf pegawai dan karyawan, serta seluruh peserta didik secara bersama-sama. Melalui pendekatan ini pula proses-proses pemberdayaan, proses humanisasi, dan proses pembudayaan dalam pelaksanaan pendidikan karakter akan berjalan secara terintegrasi dan sinergitas serta terhindar dari konflik-konflik kepentingan internal lembaga yang bisa menjadi virus utama yang mengagalkan usaha-usaha pendidikan karakter oleh guru dan dosen.

5. Pendekatan pendidikan karakter berbasis komunitas, (Sukadi, 2007) menyatakan bahwa pendekatan pendidikan karakter berbasis komunitas dilaksanakan secara sinergitas antara lembaga pendidikan dengan masyarakat sekitarnya. Karena itu, perlu ada tanggung jawab dan kerja bersama antara lembaga pendidikan orangtua/ wali siswa/mahasiswa, masyarakat dan pemeritah setempat untuk turut melaksanakan upaya pendidikan karakter.

Upaya kerja dan tanggung jawab bersama itu tidaklah cukup hanya dengan mempercayakan dan menyerahkan begitu saja kepada pihakpihak untuk pelaksanaan pendidikan karakter. Perlu ada upaya progresif dimana lembaga sekolah atau Perguruan tinggi berinisiatif untuk mensosialisasikan kepada masyarakat dan pemerintah dalam rangka meminta dukungannya dalam pelaksanaan pendidikan karakter. Efektivitas pendekatan pendidikan karakter sangat tergatung pada sejauhmana komitmen pihak-pihak untuk bersedia bersamasama bertanggung jawab mengambil inisiatif untuk mensukseskan pelaksanaan pendidikan karakter ini, setidak-tidaknya mampu menciptakan iklim dimana keluarga, masyarakat dan pemerintah dapat menjadi tauladan bagi peserta didik sebagai generasi muda.

6. Pendekatan berbasis kebijakan pendidikan,salah satu permasalahan yang dihadapi bangsa Indonesia dalam pembangunan karakter bangsa adalah masih terbatasnya perangkat kebijakan terpadu dalam mewujudkan nilai-nilai esensi Pancasila, termasuk tentunya dalam perangkat kebijakan pendidikan. Bahkan ditengarai, masih ada kebijakan-kebijakan pemerintah yang bertentangan salit sama lain. Oleh karena itu, pemerintah bekerjasama dengan dan melalui lembaga pendidikan perlu turut melahirkan berbagai instrumen kebijakan pendidikan yang terpadu dapat mewujudkan nilai-nilai esensi Pancasila bagi seluruh lapisan masyarakat, khususnya bagi warga civitas akademika(Sukadi, 2007).

Berbagai kebijakan yang mewujudkan nilai-nilai esensi Pancasila ini secara terpadu tentu akan menjadi sarana pendidikan karakter yang efektif bagi seluruh komponen civitas akademika dan masyarakat stakesholdersnya. Sebagai contoh, jika 
pemerintah dapat melahirkan satu kebijakan bahwa dalam rekruitmen calon pegawal pemerintahan dan calon guru terutama akan diambil dan lulusan perguruan tinggi yang memiliki prestasi akademis dan integritas kepribadian yang tinggi, tentu kebijakan ini akan menjadi sarana pendidikan karakter yang efektif untuk meningkatkan kualitas lulusan perguruan tinggi di satu sisi dan kualitas sumber daya manusia pemerintahan dan guru di sisi lain.

\section{KESIMPULAN}

Berdasakan pembahasan yang telah diuraikan, maka dapat ditarik beberapa kesimpulan bahwa pendidikan karakter mengambil aspek yang dominan dan utama dalam pelaksanaan program pendidikan. Demikian pula pendidikan karakter mengambil domain yang terdalam dan kompleks dalam pengembangan kompetensi manusiawi. Sangatlah tidak mudah, karena itu, untuk melakukan dan mengembangkan satu pendekatan pendidikan karakter yang efektif dan efisien. Pendidikan karakter pada abad 21 sesungguhnya merupakan proses pemberdayaan (empowering) potensi peserta didik proses humanisasi (humanizing), dan proses pembudayaan (civilizing). Sebagai proses pemberdayaan, pendidikan karakter pada dasarnya adalah usaha sadar untuk memberdayakan dan mengembangkan seluruh potensi peserta didik untuk membentuk karakter baik (good character). Pada hakikatnya tidak ada proses pendidikan yang bebas nilai, maka model-model pembelajaran pendidikan karakter pada abad 21 yang berbasis pada pendidikan nilai dan moral yaitu model pembelajaran penanaman nilai, berbasis perkembangan penalaran moral,analisis nilai dan project citizen, efektif digunakan membantu peserta didik mengembangkan kompetensi menjadi warga negara yang baik dalam arti demokratis dan partisipatif.

\section{UCAPAN TERIMA KASIH}

Terima kasih penulis ucapkan kepada Tim Editor E-Journal Obsesi yang sudah memberikan kesempatan sehingga jurnal ini siap untuk diterbitkan, tidak lupa pula saya ucapkan rangkaian terima kasih yang sebesar besarnya kepada reviewer yang sudah mau meluangkan waktunya untuk mereview serta memberikan banyak masukan sehingga jurnal ini lebih sempurna. Untuk semua teman sejawat dosen dosen Universitas Pahlawan Tuanku Tambusai yang telah memberikan semangat dalam penulisan ini sehingga penulis dapat menyelesaikan tepat pada waktunya.

\section{DAFTAR PUSTAKA}

Budimansyah. (2010). Penguatan Pendidikan Kewarganegaraan Untuk Membangun Karakter Bangsa. bandung: Widya Aksara Press.

Elmubarok, Z. (n.d.). Membumikan Pendidikan Nilai. bandung: alfabeta.

Fauziddin, M. (2016). Pembelajaran Agama Islam Melalui Bermain pada Ank Usia Dini (Studi Kasus di TKIT Nurul Islam Pare Kebupaten Kediri Jawa Timur), 2(2), 8-17.

Koesoema. (2010). Pendidikan Karakter: Strategi Mendidik Anak di Zaman Global. jakarta: Grasindo.

Pascalian Hadi Pradana. (2016). Pengaruh Permainan Balok Angka Terhadap Kemampuan Mengenal Lambang Bilangan pada Anak Usia Dini. PAUD TAMBUSAI, 2(2), 18-25.

Sukadi. (2007). Belajar dan Pembelajaran sebagai Yadnya. Singaraja: undiksha. 